\title{
Connectivity among Wetlands of EPA of Banhado Grande, RS
}

\author{
Conetividade entre Áreas Úmidas, APA do Banhado Grande, RS
}

\author{
João Paulo Delapasse Simioni ${ }^{1}$, Laurindo Antonio Guasselli ${ }^{1}$ and Cecilia Balsamo Etchelar ${ }^{1}$ \\ ${ }^{1}$ Universidade Federal do Rio Grande do Sul, Porto Alegre, RS, Brasil \\ E-mails: geojoaopaulo@gmail.com (JPDS), laurindo.guasselli@ufrgs.br (LAG), cecibalsamo@gmail.com (CBE)
}

Received: July 06, 2016 - Revised: October 04, 2016 - Accepted: November 05, 2016

\begin{abstract}
The Environmental Protection Area (EPA) of Banhado Grande, located in the Metropolitan Region of Porto Alegre, comprises three areas of marshes, the Banhado Chico Lomã, the Banhado Grande and Banhado dos Pachecos. In periods of large flood pulses extensive flooded areas are formed between these wetlands and the river Gravataí floodplain, establishing a connectivity between the Wetlands of EPABG. This connectivity indicates that there is an interaction between these wetlands, such as exchange of nutrients, sediments and living organisms. Thus, this study aims to map extensive floodable areas associated with large flood pulses and to analyze the connectivity areas in EPABG. For this, the work is structured in three steps: i) choice of satellite images between the years 2000 to 2015 to identify largest flood pulses; ii) mapping of floodable areas in large flood pulses using images Normalized Difference Index Water (NDWI); and iii) analysis of the connectivity among wetlands. As the results, in large flood pulses, with precipitation greater than $247 \mathrm{~mm}$, in the 30 days prior to the date of the image, establishing a large area of connectivity between the wetlands, forming on the polygon defined by elevation of 11 metres, two types of connectivity: wetlands-wetlands connectivity, allowing interactions among environments with turf and lagoon deposits; and wetlands-stream connectivity, linking the alluvial and floodplain of the Gravataí River deposits with the background lagoon and paludals deposits. Already, in flood pulses of flooding with rainfall less than or equal to $200 \mathrm{~mm}$, in the last 30 days, the flooded area appears fragmented inside the polygon associated at an elevation of 11 metres, mainly in the corridor between the marshes Grande and the Pachecos, that does not connect by flood, forming just wetlands-stream connectivity. Thus, the characterization of the flood pulses and connectivity become fundamental to the understanding of the dynamic of wetlands, because, make aware of for the need to preserve these areas of importance for flood control, microclimate regulation and maintenance of biodiversity.
\end{abstract}

Keywords: Flood pulses; Marshes; Flood plain; Rainfall; River Gravataí.

\section{RESUMO}

A Área de Proteção Ambiental do Banhado Grande (APABG), localizada na Região Metropolitana de Porto Alegre, compreende três áreas de banhados, o Banhado Chico Lomã, o Banhado Grande e o Banhado dos Pachecos. Em períodos de grandes pulsos de inundação extensas áreas inundáveis são formadas entre esses banhados e a planície de inundação do rio Gravataí, estabelecendo uma conectividade entre as Áreas Úmidas (AUs) da APABG. Essa conectividade faz com que haja interações entre essas AUs, como troca de nutrientes, sedimentos e organismos vivos. Deste modo, este trabalho tem por objetivo mapear as áreas inundáveis associadas aos grandes pulsos de inundação e analisar as áreas de conectividade na APABG. Para isto, estruturou-se o trabalho em três etapas: i) escolha de imagens de satélites e de dados de precipitação, entre os anos 2000 a 2015 para identificação dos grandes pulsos de inundação; ii) mapeamento das áreas inundáveis nos grandes pulsos de inundação, utilizando imagens de Índice de Diferença Normalizada da Água (NDWI); e iii) análise da conectividade entre as Áreas Úmidas. Conforme os resultados, em grandes pulsos de inundação, com precipitação pluviométrica maior que $247 \mathrm{~mm}$, nos 30 dias anteriores à data da imagem, se estabelece uma grande área de conectividade entre as áreas úmidas, formando no polígono delimitado pela cota de 11 metros, dois tipos de conectividade: wetlands-wetlands connectivity, permitindo interações entre ambientes com depósitos paludiais e de fundo lagunar; e wetlands-stream connectivity, interligando os depósitos aluvionares e de planície de inundação do rio Gravataí com os depósitos de fundo lagunar e paludiais. Em pulsos de inundação com precipitação acumulada menor ou igual a $200 \mathrm{~mm}$, nos últimos 30 dias, a superfície inundável apresenta-se fragmentada dentro 
do polígono associado à cota de 11 metros, principalmente no corredor entre os banhados Grande e dos Pachecos, que não chegam a se conectar pela inundação, formando apenas a wetlands-stream connectivity. Assim, a caracterização dos pulsos de inundação e da conectividade tornam-se fundamentais para o entendimento da dinâmica das AUs, pois, atentam para a necessidade de preservação destas áreas de grande importância para o controle de inundações, regulação microclimática e manutenção da biodiversidade.

Palavras-chave: Pulsos de inundação; Banhados; Planície de inundação; Precipitação pluviométrica; Rio Gravataí.

\section{INTRODUCTION}

The Environmental Protection Area of Banhado Grande (EPABG), located in the Metropolitan Region of Porto Alegre (MRPA), comprises three areas of mashes, Banhado Chico Lomã, Banhado Grande and Banhado dos Pachecos.

These areas form an extensive composition of Wetlands in the basin of Gravataí river. Meneghetti (1998) defines these areas as Banhado Grande System (BGS). For Guasselli, Etchelar and Belloli (2013), BGS is bordered by altimetry quota of $20 \mathrm{~m}$, and consists, according to Accordi and Hartz (2006), of an area continues to swamps, flooded land and paddy fields. In the 1970s, however, part of the Gravataí river was rectified with the intention of draining wetlands, seeking to expand the areas destined to irrigated rice cultivation.

In periods of great flood pulses, a connectivity is established among the wetlands of EPABG, forming an extensive flood area between Banhado Grande, Banhado dos Pachecos and the floodplain of Gravataí river. The connectivity refers to interactions between different water bodies, such as lowland areas, marshes area and between aquatic and riparian systems.

In the literature, the term connectivity appears alone or associated with: ecological connectivity, geohylogrological, hydrologic, meandering, morphologic, functional, structural, among others. For Amoros and Roux (1988); Ward and Stanford (1995), ecological connectivity refers to interactions and movement of water, sediment, nutrients, wastes and living organisms. Pringle (2003) addresses the connectivity calling it hydrologic connectivity. Already Rocha and Rocha (2007) address the hydrodynamic connectivity active in river flood-plain system. For Junk, Bayley and Sparks (1989) seasonal flooding, with its flood cycles, high, ebb and draught define the flood pulses.

In research involving connectivity, Rocha (2010) stands out in the study on the interactions between geomorphological characteristics and the connectivity of aquatic environments and features of the fluvial river-plain system. In this study, the forms with genesis in the current fluvial regime are less stable, allowing allogeneic processes to guarantee greater geomorphic and evolutionary dynamism of the water bodies, due to the greater degree of connectivity.

Rocha (2011a) in the geomorphological mapping of the floodable areas in a fluvial plain identified three flood zones related to the hydrological pulses. Whereas, Rocha (2011b) discusses the hydrodynamic processes in river floodplain systems, in an associative interpretation between the features generated by geomorphic processes and the main dimensions of hydrodynamic connectivity between channel and floodplain environments.

Guimarães (2009) analyzed the relationships between connectivity and the fish community, using GIS and landscape ecology concepts, in 39 lagoons located on the northern coast of
Rio Grande do Sul. According to the author, lagoons with high connectivity values Species richness.

Rocha (2015) analyzed the hydrosedimentological structural and functional connectivity in a hydrographic basin, based on the relationship of the intensity of the surface runoff, water production and sediment concentration in different stretches in the basin.

The definitions of wetlands are many, and for the most part, confusing (CUNHA; PIEDADE; JUNK, 2015; JUNK; PIEDADE, 2015). The most accepted was proposed by the Ramsar Convention (RAMSAR, 1971), and adapted by Scott and Jones (1995, p. 4), where, according to the authors, wetlands

[...] are plains, swamps, peatlands or water, whether natural or artificial, permanent or temporary, With still or flowing water, sweet, brackish or salt water, including areas of small waters where the depth at low tide does not exceed 6 meters.

However, according to Guasselli (2005), this definition is very broad.

Cowardin et al. (1979), for example, highlight the dominance in wetlands of water-saturated soils, where plant and animal communities live on its surface. According to the authors wetlands are transition areas between terrestrial and aquatic environments, where the water table is usually close to the surface or the land is covered by surface water.

For Cunha, Piedade and Junk (2015) wetlands are ecosystems at the interface between terrestrial and aquatic environments, continental or coastal, natural or artificial, permanently or periodically flooded by shallow water or with soaked, sweet, brackish or salted soils, with communities of plants and animals adapted to the Its water dynamics.

According to Rolon, Homem and Maltchik (2010) are ecosystems that remain flooded for a long enough time, allowing the establishment of soggy soils and aquatic plants.

The wetlands among the Grande and Pacheco wetlands and the floodplain of the Gravataí River forms a delimited corridor based on the 11 meter elevation (FRAGOSO JÚNIOR; NEVES, 2015). In this area connectivity plays a significant role in periods of large flood pulses. Yet, among the main hydrologic functions of wetlands is the ability to store and release water, working in flood control and discharge of water in times of drought, known as effect "sponge" (DIEGUES, 1990).

Due to its importance, the Ministry of the Environment (MMA) in 2007 included the area comprised by this corridor in the map of the priority areas for biodiversity conservation (ROSA, 2009). The scale of 1: 6,000,000, however, makes it impossible to identify the area to be preserved.

Despite the declared importance, according to Rio Grande do Sul (2014) there is a project for a dam on the river Gravataí, with the purpose of containing the floods in the low course of the 
river. Flooding second Fragoso Júnior and Neves (2015) an area of approximately 10,000 ha, including the entire wetland relative to the $11 \mathrm{~m}$ height, directly interfering with the natural dynamics. From the environmental point of view, this has an extremely negative impact on the maintenance of biodiversity, since it will permanently flood the wetlands of the EPABG, which should be protected for conservation purposes.

In this way it is understood that the connectivity in periods of great flood pulses is responsible for the interactions between wetlands in the watershed. Thus, this work aims to map the flood areas associated with large flood pulses in the EPABG and to analyze the areas of connectivity using remote sensing techniques.

Location and characterization of the study área

The Environmental Protection Area of the Banhado Grande (EPABG) was established by State Decree No. 38.971/1998. According to Art. 15 of the National System of Conservation Units (BRASIL, 2000) " [...] it is an area in general extensive, with a certain degree of human occupation, endowed with abiotic, biotic, aesthetic or cultural attributes especially important for the quality of life and The well-being of human populations", and its basic objectives are to protect biological diversity, to discipline the occupation process, and to ensure the sustainability of the use of natural resources.

Located in the Metropolitan Region of Porto Alegre (MRPA), EPABG has an area of 136,935 ha, covering the municipalities of Santo Antônio da Patrulha, Gravataí, Viamão and Glorinha. According to Nielsen (1994), it comprises 07 geomorphological units. It stands out in the corridor that connects the bathed, the presence of plains and lagoon terraces, and of the fluvio-coluvionar depression. In relation to the geology, the presence of deposits of lagoon plains, deposits of flood plain, alluvial deposits and peat bogs (Figure 1) stands out.

The formation of the area comprised by the BGS dates back to the main transgressive-regressive episodes occurring in the quaternary period (TOMAZELLI; VILLWOCK, 2000). This area covers a set of wetlands in the EPABG, formed by the floodplain of the Gravataí river and by lagoon bottom environments, responsible for the connection between the Grande and the Pachecos plains (paludal environments).

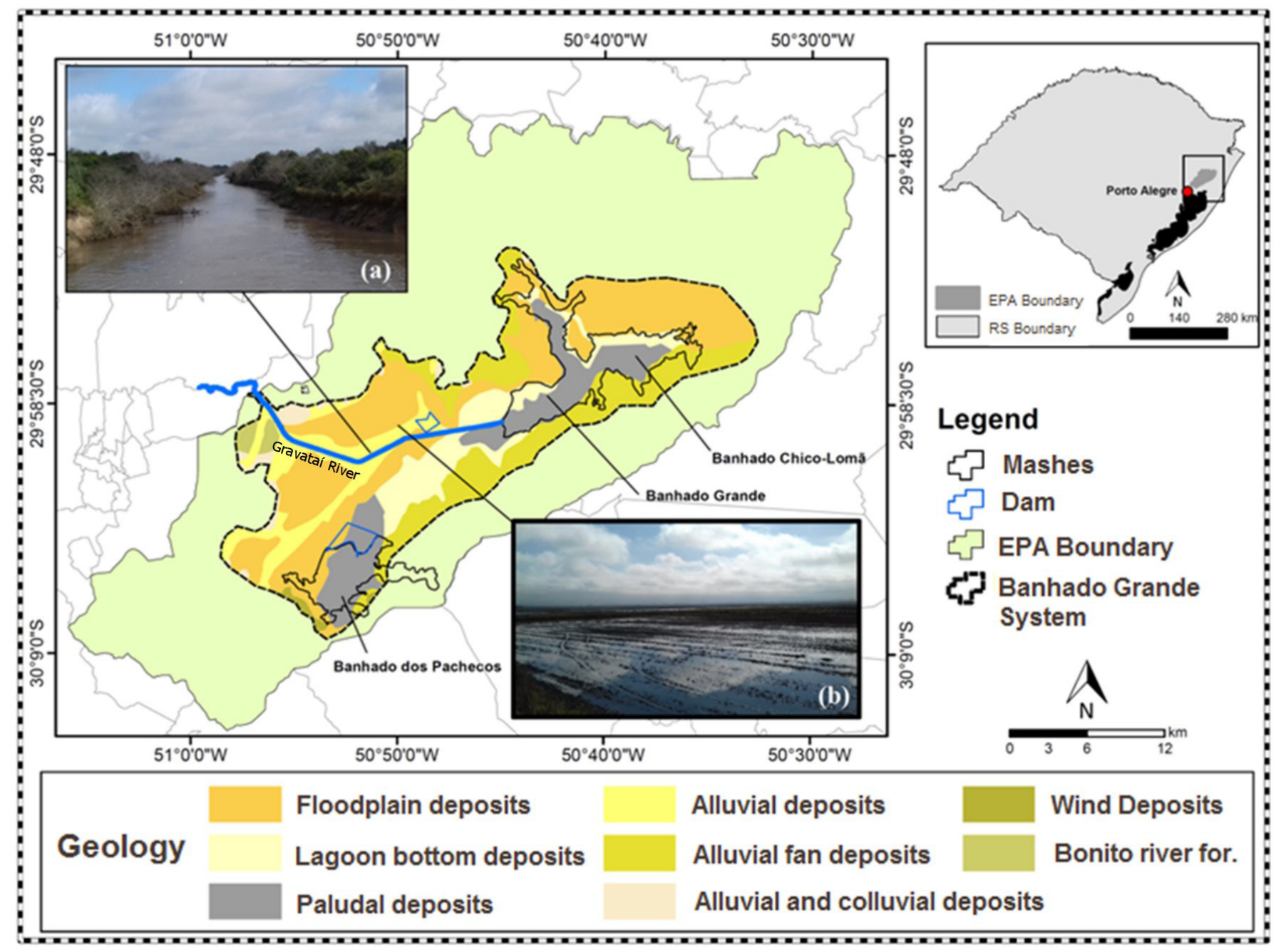

Figure 1. Location of the Environmental Protection Area of Banhado Grande-RS, and geology of the Banhado Grande System (BGS). (A) photo of the Gravataí river channel; (B) rice cultivation within the BGS. 
In the area of the polygon delimited by the quota of 11 meters were constructed two dams for irrigation of rice cultivation. The first, at the end of the decade of 1980, with 119 ha, is located on alluvial deposits. The second dam, built in the early 1990s, was used to irrigate the rice produced at the Seeds of Sepé settlement of the Landless Movement (LM), with 574 ha, on the bog deposit.

The Banhado Grande EPA is one of the most important wetlands in Rio Grande do Sul, and its biodiversity is known for the great diversity of birds, especially migratory birds, and is considered by experts as of relevance to global conservation (ACCORDI, 2003).

In relation to the climate, the EPABG is included in the subtropical III climate (ROSSATO, 2011), classified as humid and with longitudinal variation of average temperatures, with the average annual temperature varying between 17 and $20^{\circ} \mathrm{C}$, and a rainfall regime between 1700 and $1800 \mathrm{~mm}$ per year.

\section{MATERIALS AND PROCEDURES}

The execution of this research to identify and map the connectivity of the Wetlands of the APM of the Banhado Grande was structured in three stages: i) choice of satellite images and acquisition of pluviometric data between the years 2000 to 2015 to identify large flood pulses In the EPABG; ii) mapping of flood areas on large flood pulses within the 11-meter elevation; And iii) analysis of the connectivity between Wetlands.

\section{Choice of satellite imagery and identification of large flood pulses}

Images from the Landsat 5 Thematic Mapper (TM), Landsat 7 Enhanced Thematic Mapper Plus (ETM +) and Landsat 8 (TM) satellites were used. on the site of the USGS (United States Geological Survey), the platform E arth Explorer (http://earthexplorer.usgs.gov/). The period of analysis comprises 16 years, between $01 / 01 / 2000$ and $12 / 31 / 2015$. This period allowed to cover a climatic dynamics in the EPABG, with the presence of El Niño (02-03, 04-05, 06-07), La Niña (00-01 and 07-08) and neutral years, based on information from the CPTEC (BRASIL, 2015).

For this work, the images that presented any cloud coverage over the study area were discarded, leaving 83 images. In HIDROWEB platform of the National Water Agency (ANA, 2016) were obtained precipitation data, the rainfall station Glorinha, for the last 30 days of the date of acquisition of each One of 83 images.

Subsequently, the total rainfall for the previous 30 days of each of the 83 images was calculated. When generating the NDWI images, it was verified that in rainfall accumulated less than $200 \mathrm{~mm}$, in the last 30 days of the date of obtaining the image, the flood surface is small.

Therefore, it was decided to use images, where the total rainfall, during the 30 days prior to the date of acquisition of the satellite image, was greater than $200 \mathrm{~mm}$. In this way, four images were selected in which the pluviometric values were equal to or greater than $200 \mathrm{~mm}$ (Table 1).
After selection of the Landsat images, held the atmospheric correction by ATCOR2 tool (Atmospheric Correction), the ERDAS Imagine 2014 software using the MODTRAN-4 code (Moderate Resolution Atmospheric Transmittance Algorithm).

The atmospheric correction removes the effects of the atmosphere on the reflectance of the images. For this work, we chose to use the MODTRAN-4 code, since it is able to estimate the values of the given atmospheric condition, and thus determine the surface radiance and then the reflectance. The model estimates are based on atmospheric information observed at the moment of image acquisition.

\section{Mapping of flood areas on large flood pulses}

In order to map the floodable areas in the large flood pulses in the EPABG, the Normalized Water Difference Index (NDWI) was used. Gao (1996) proposes the NDWI using near infrared and medium infrared bands, in order to highlight, among other factors, the water stress of the vegetation.

For the calculation of the NDWI with images of the Landsat satellites 5 and 7, Equation 1 was used:

$$
\mathrm{NDWI}=\frac{\mathrm{B} 2-\mathrm{B} 4}{\mathrm{~B} 2+\mathrm{B} 4}
$$

In which: B2 - wavelength of green; And B4 - near infrared.

And, for the calculation of the NDWI with Landsat 8 images, Equation 2 was used:

$$
\mathrm{NDWI}=\frac{\mathrm{B} 3-\mathrm{B} 5}{\mathrm{~B} 3+\mathrm{B} 5}
$$

In which: B3 - wavelength of green; And B5 - near infrared.

The NDWI value ranges from -1 to 1 . McFeeters (1996) defined zero as the threshold. That is, the type of coverage is water if $\mathrm{NDWI} \geq 0$ and not water if $\mathrm{NDWI} \leq 0$ (BRENNER; GUASSELLI, 2015).

The flooded areas were computed with the sum of the pixels with NDWI $>0$, for the four images used, identifying the connectivity, and its relation with the rainfall values.

The polygon delimited by the height of 11 meters was adopted as the study area. To set this quota, they were used images SRTM v3 (Shuttle Radar Topography Mission) (FARR et al., 2007) obtained from the Earth Explorer platform (USGS, 2016), with a spatial resolution of 30 meters. As Santos, Gaboardi and Oliveira (2005), these images present a Root Mean Square Error (RMSE) of $7.642 \mathrm{~m}$. As shown in Figure 2, which is the same as that of the SRTM image, which is compatible with the delimitation of Fragoso Júnior and Neves (2015) from a topographic survey to define the flooded area in a dam project.

To cover the study area, four SRTM images were acquired, and the mosaic was made. From the mosaic was obtained the level

Table 1. Images used in the study.

\begin{tabular}{ccc}
\hline $\begin{array}{c}\text { Date of the } \\
\text { image }\end{array}$ & Satellite & $\begin{array}{c}\text { Total rain 30 days } \\
\text { previous }(\mathbf{m m})\end{array}$ \\
\hline $21 / 10 / 2000$ & Landsat 7 & 250.8 \\
$20 / 09 / 2009$ & Landsat 5 & 201.2 \\
$31 / 08 / 2013$ & Landsat 8 & 247.5 \\
$21 / 10 / 2014$ & Landsat 8 & 204.7 \\
\hline
\end{tabular}



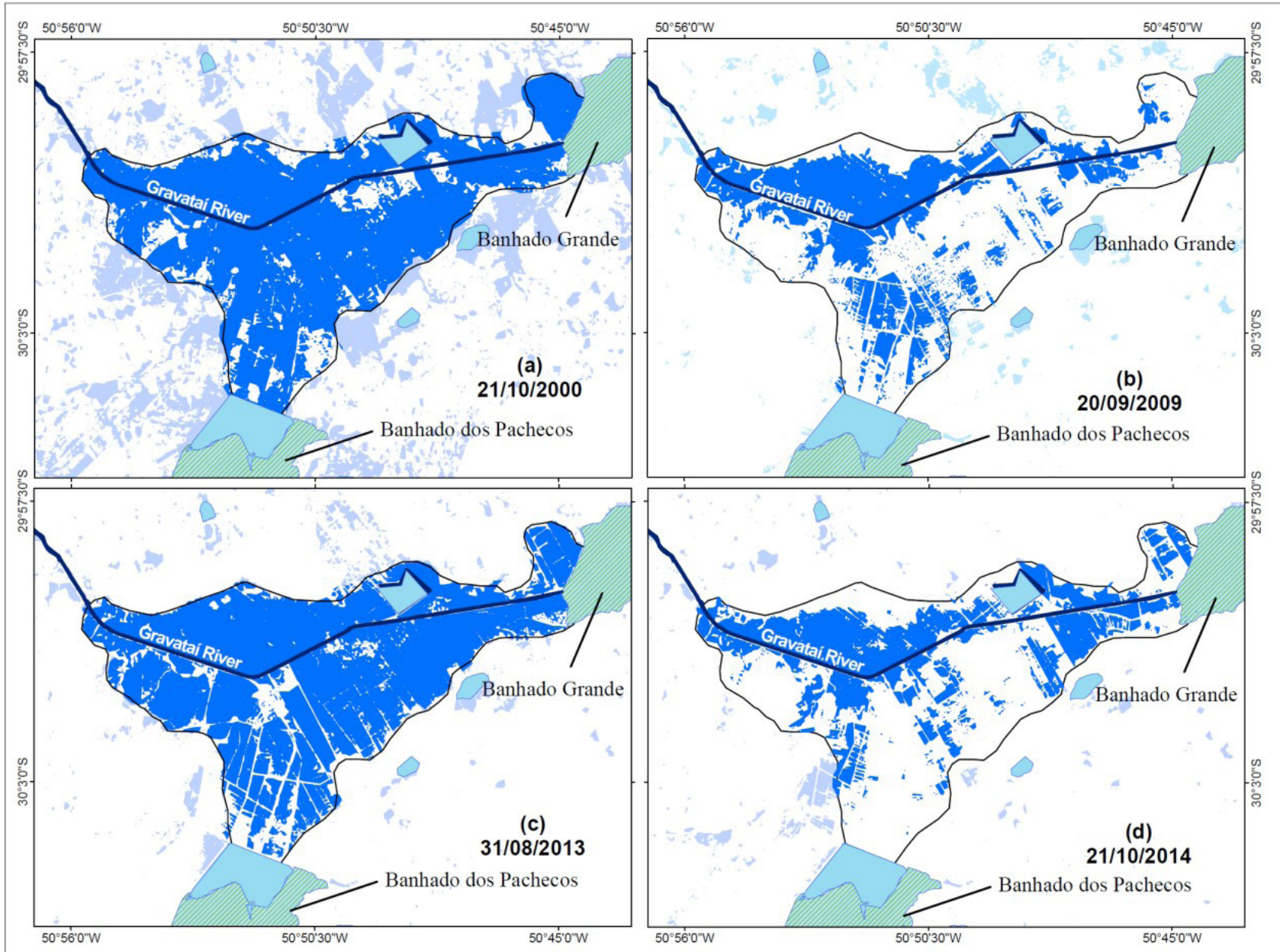

Area of the polygon with quota of 11 meters 9,477.00 hectares

\begin{tabular}{ccc}
\hline Date & $\begin{array}{c}\text { Flooded area in quota } \\
11 \text { meters (ha) }\end{array}$ & $\begin{array}{c}\text { Accumulated rainfall } \\
\text { in the last 30 days (mm) }\end{array}$ \\
\hline $21 / 10 / 2000$ & 7580.72 & 250.8 \\
$20 / 09 / 2009$ & 3331.54 & 201.2 \\
$31 / 08 / 2013$ & 7412.26 & 247.5 \\
$21 / 10 / 2014$ & 3159.42 & 204.7 \\
\hline
\end{tabular}

\section{Legend}

Flooded area inside of quota of 11 meters

Flooded area outside of quota of 11 meters

Dam

Marshes

3 Quota of 11 meters

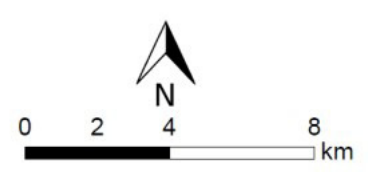

Figure 2. Flooded area from images of NDWI.

curve referring to the elevation of 11 meters (with a total area of 9,477 hectares of the polygon). Subsequently, the NDWI images were overlaid with the polygon referring to the 11-meter elevation and the quantification of the floodable areas located within the said boundary was performed.

\section{Analysis of the connectivity between the Wetlands of EPABG}

The analysis of the connectivity of wetlands in the EPABG was approached from the methodology proposed by Vanderhoof, Alexander and Todd (2016). Based on this methodology, it is possible to identify the levels of connectivity in a river-flood plain system, and classify them according to their characteristics. Thus, the types of connectivity analyzed for EPABG were connectivity between wetlands (wetlands, wetlands connectivity) and connectivity between wetlands and the river channel (wetlands-stream connectivity).

To characterize the types and levels of connectivity, the geological map (Figure 1) was superimposed on the NDWI images, thus identifying the compartments to which the connectivity is associated.

After the identification of the types of connectivity between the EPABG wetlands, the areas flooded by the flood pulses were quantified, in the polygon referring to the 11 meters dimension, and their relation with the rainfall values. 


\section{RESULTS AND DISCUSSIONS}

The mapping of flood areas associated with large flood pulses from NDWI images for the four satellite imagery acquisition dates is shown in Figure 2.

Figure 2a, dated 10/21/2000, presents the largest flooded area $(7,851 \mathrm{ha})$, equivalent to $83 \%$ of the area associated with the 11 meter elevation. In the 30 days prior to the acquisition of this image, a total of $250.8 \mathrm{~mm}$ rained at Glorinha / RS meteorological station. The average rainfall is approximately $120 \mathrm{~mm}$ in the month of September and $115 \mathrm{~mm}$ in October, ie, it rained in the area of the EPABG more than twice the average.

It can be seen in Figure 2a that the connectivity of wetlands related to large flood pulses establishes a large inundated area forming two types of connectivity proposed by Vanderhoof, Alexander and Todd (2016): the first (wetlands, wetlands connectivity), connects the Great bathed and Pachecos interconnecting two geological compartments: lagoon background environments and palustrine deposits (peat bogs); already the second connects the Great bathed and Pachecos and Gravatai River floodplain (wetlands-stream connectivity), connecting palustrine and lagoon bottom deposits with alluvial deposits and Gravatai River floodplain.

It is used the NDWI proposed by Gao (1996), since it has the advantage of highlighting, among other factors, the water stress of the vegetation, in comparison to the NDWI proposed by McFeeters $(1996,2013)$ Maximize the water reflectance. Thus, their use of the NDWI proposed by Gao (1996) contributes more adequately to the analysis of wetlands when in events caused by floods, as in the case of this study.

In Figure 2b, September 20, 2009, the flood area for a cumulative precipitation of $201.2 \mathrm{~mm}$ was $3,331.54$ ha, equivalent to $35 \%$ of the area relative to the 11 -meter elevation. This date was the one with the lowest rainfall, but it was not the one with the lowest flooded area.

It should be noted that a large part of the flood shown in Figure $2 b$ is on the northern margin of the rectified Gravatai River, in the area known as Lagoa da Anastacia. In this area, Brenner (2016) proposed measures for the renaturalization of the meanders, based on bioengineering techniques, since the meanders are still active and periodically flooded.

Also, highlights the existing connectivity between the river and the Gravataí Banhado Grande (wetland-stream connectivity). Although this connectivity is fragmented within the polygon with an elevation of 11 meters, it is verified that the paludial deposit of the Banhado Grande and the alluvial and floodplain deposits of the Gravataí River are interconnected through the flood.

Figure $2 \mathrm{c}$ represents the flooded area from NDWI images, dated August 31, 2013, with accumulated rainfall of $247.5 \mathrm{~mm}$. The average for the month of August in the EPABG is $130 \mathrm{~mm}$, that is, it rained in the month of August 2013, $117.5 \mathrm{~mm}$ more than the historical average for this month. The flooded area forms a triangle on the height of 11 meters, and again have two types of connectivity: the first integrating plated Grande and Pachecos the river Gravatai (wetland-stream connectivity); and the second connecting compartments associated with peatlands (wetlands) to deposit lagoon bottom (wetland-wetland connectivity). The flooded area is 7,412 ha, equivalent to $78 \%$ of the area.
This area comprised by the triangle, is almost entirely occupied by rice cultivation (GUASSELLI; ETCHELAR; BELLOLI, 2013). In relation to rice crops, Rolom (2013) points out that they present a series of characteristics in common with the wetlands, being considered by several researchers as artificial wetlands.

However, rice plantations can not be considered substitutes for natural wetlands, since several aquatic species do not occur in these managed areas. Paddy fields sustain only a fraction of the biodiversity of wetlands. Its importance lies in the conservation of the species that present some resistance to the different management practices adopted in the plantations (ROLOM, 2013).

Figure $2 d$ shows the flooded area referring to 10/21/2014, considering the cumulative rainfall of $204.7 \mathrm{~mm}$. In this flood pulse, much of the area relative to the 11-meter elevation is not flooded. Flooding restricted to the plain of the river Gravatai from the Lagoon Anastácia to the Banhado Grande (wetland-stream connectivity), and connects the paludial deposit with floodplain deposits. The flooded area was 3,159 ha, equivalent to 33\% of the area at an altitude of 11 meters.

Although there is no connection between the wetlands (wetlands, wetlands connectivity), stands out in Figure $2 \mathrm{~d}$ the importance of flood river-plain system (ROCHA, 2010), which has highly complex characteristics, in terms of hydrodynamics, Connectivity and geoecological processes. In these environments, the alternation of periods of flooding and water recession promotes large transformations in habitats, ranging from lentic to lotic and aquatic to terrestrial (ROCHA, 2011a).

In Figure 3, with daily rainfall between 09/21/2000 and $21 / 10 / 2000$ (date of first image), precipitation is well distributed, with 14 rainy days. The maximum precipitation values are $58 \mathrm{~mm}$ and $51 \mathrm{~mm}$. The distribution of the rainfall was responsible for the maintenance of the flood pulse, so that the total flooded area, on $10 / 21 / 2000$, in the polygon with an elevation of 11 meters, was 7,581 ha.

Figure 4, of 09/20/2009, presents the lowest rainfall, however, it does not present the smallest total flooded area. This fact may be related to the daily distribution of precipitation in the last 30 days.

The precipitation distribution presented a homogeneity, with its maximum peaks verified on 03/09/2009, 09/08/2009

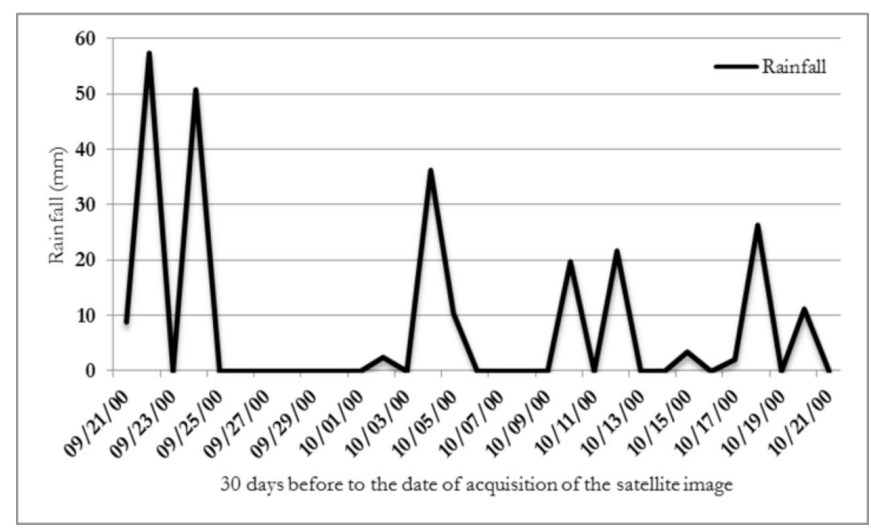

Figure 3. Daily rainfall in the Glorinha meteorological station, between $09 / 21 / 2000$ to $10 / 21 / 2000$. 
and $09 / 12 / 2009$, when it rained, $26 \mathrm{~mm}, 30 \mathrm{~mm}$ and $47 \mathrm{~mm}$, respectively.

Also, rainfall occurred on 09/18/2009 (14 mm), which was possibly responsible for keeping the area flooded, when compared to the image referring to Figure $2 \mathrm{~d}$, when it rained more, but the Flood area was lower.

Figure 5 refers to the daily precipitation between $07 / 30 / 2013$ to $08 / 31 / 2013$. For this period, the precipitation peak observed on $08 / 25 / 2013$ stands out, when it rained $72 \mathrm{~mm}$ in 24 hours. This peak rainfall was instrumental in the formation of two types of connectivity (wetlands,wetlands and wetlands connectivity-stream connectivity) (VANDERHOOF; ALEXANDER; TODD et al., 2016).

The flooded area relative to the 11-meter elevation, in part, corresponds to the project to create a dam to contain floods (RIO GRANDE DO SUL, 2014). According to the project, the bus will be close to the Anastacia Lagoon and will flood an area of approximately 10,000 ha.

Figure 6 shows the daily precipitation between 9/21/2014 to $10 / 21 / 2014$, when 17 rainy days occurred. It stands out the period between $11 / 10 / 2014$ to $10 / 21 / 2014$, when it rained in the meteorological station of Glorinha, $167.3 \mathrm{~mm}$.

The total area flooded for the flood pulse verified on $10 / 21 / 2014$ was $3,149.52$ hectares. In this way, it is possible to observe that, although it presents higher rainfall values when compared to the image of 2009 , the flooded area was smaller.

It is understood that this occurred due to the fact that the precipitation has a more homogeneous distribution, compared to the image of 2009, since, it presents the first peak of precipitation on $09 / 26 / 2014$ (21 mm) and remains of the day 10/10/2014 until $10 / 10 / 2014$, without the occurrence of precipitation.

According to Junk, Bayley and Sparks (1989), pulsating systems (such as rivers and wetlands) behave as permanent imbalance systems, in which time variability is a complex function dependent on the inputs and outputs of energy and materials at different sites in the basin (NEIFF, 1999; CUNHA; PIEDADE; JUNK, 2015).

In view of this temporal variability, it is possible to observe that the EPABG wetlands tend to present a larger flooded surface when the rainy days are continuous and well distributed, when compared to isolated events of great daily precipitation. As, for example, occurred on 10/18/2014, when it rained $80 \mathrm{~mm}$ in 24 hours. At that date, the flood area was lower than that of $09 / 20 / 2009$, when the maximum peak was $47 \mathrm{~mm}$, but rainfall was well distributed, especially in the last fortnight of the image.

Figure 7 represents the connectivity formed by the sum of the flooded areas relative to the four dates. It is observed a similarity in the flood pulses verified in the images of 9/20/2009 and $10 / 21 / 2014$, when it rained, in the previous 30 days, a cumulative of $201.2 \mathrm{~mm}$ and $204.7 \mathrm{~mm}$, respectively.

The presence of the connectivity in Figure 7 occurs when the precipitation values are greater than $247 \mathrm{~mm}$, when the formation of a flood triangle is identified, connecting the Wetted areas associated to Grande, Pachecos and the floodplain of the Gravataí river. This fact demonstrates the importance of the preservation of this area, serving as a subsidy for the control of floods, climate regulation, maintenance of biodiversity and exchange of sediments and living organisms.

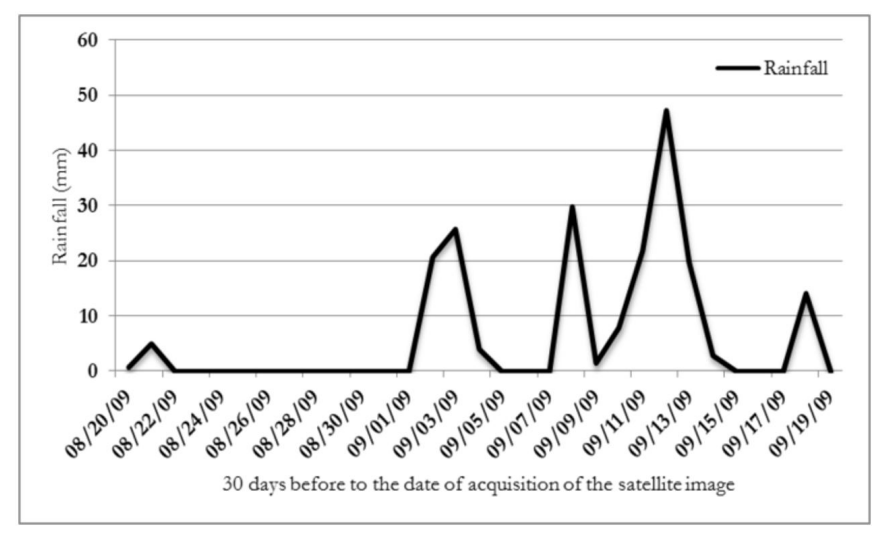

Figure 4. Daily rainfall at Glorinha meteorological station, between 08/20/2009 and 09/20/2009.

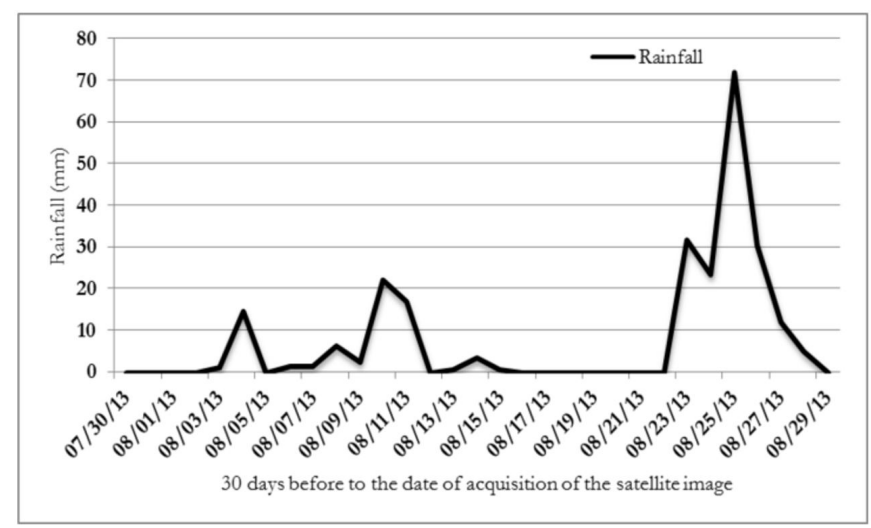

Figure 5. Daily rainfall at Glorinha meteorological station, between $07 / 30 / 2013$ and $08 / 31 / 2013$.

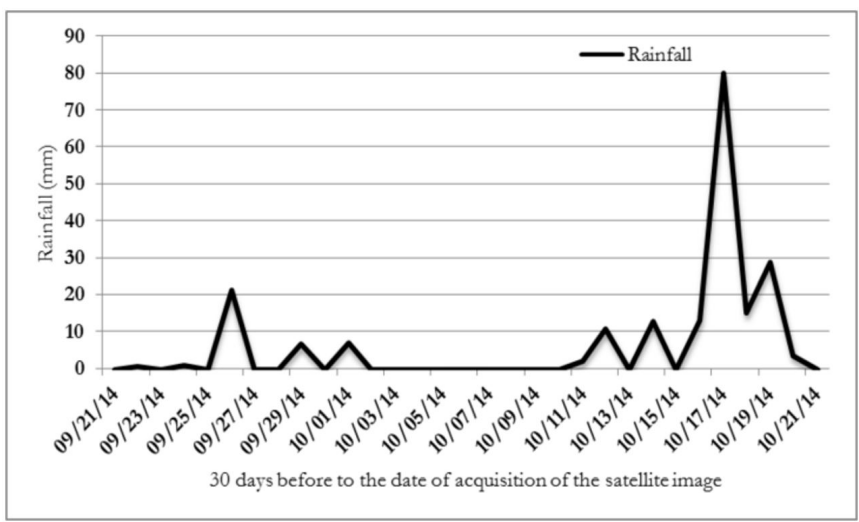

Figure 6. Daily rainfall in the Glorinha meteorological station, between $09 / 21 / 2014$ and 10/21/2014.

Still, this area is compatible with the ecological corridor of the Wetland deer (dichotomus Blastocerus) proposed by Krob et al. (2015), being another justification of the importance for its conservation. 


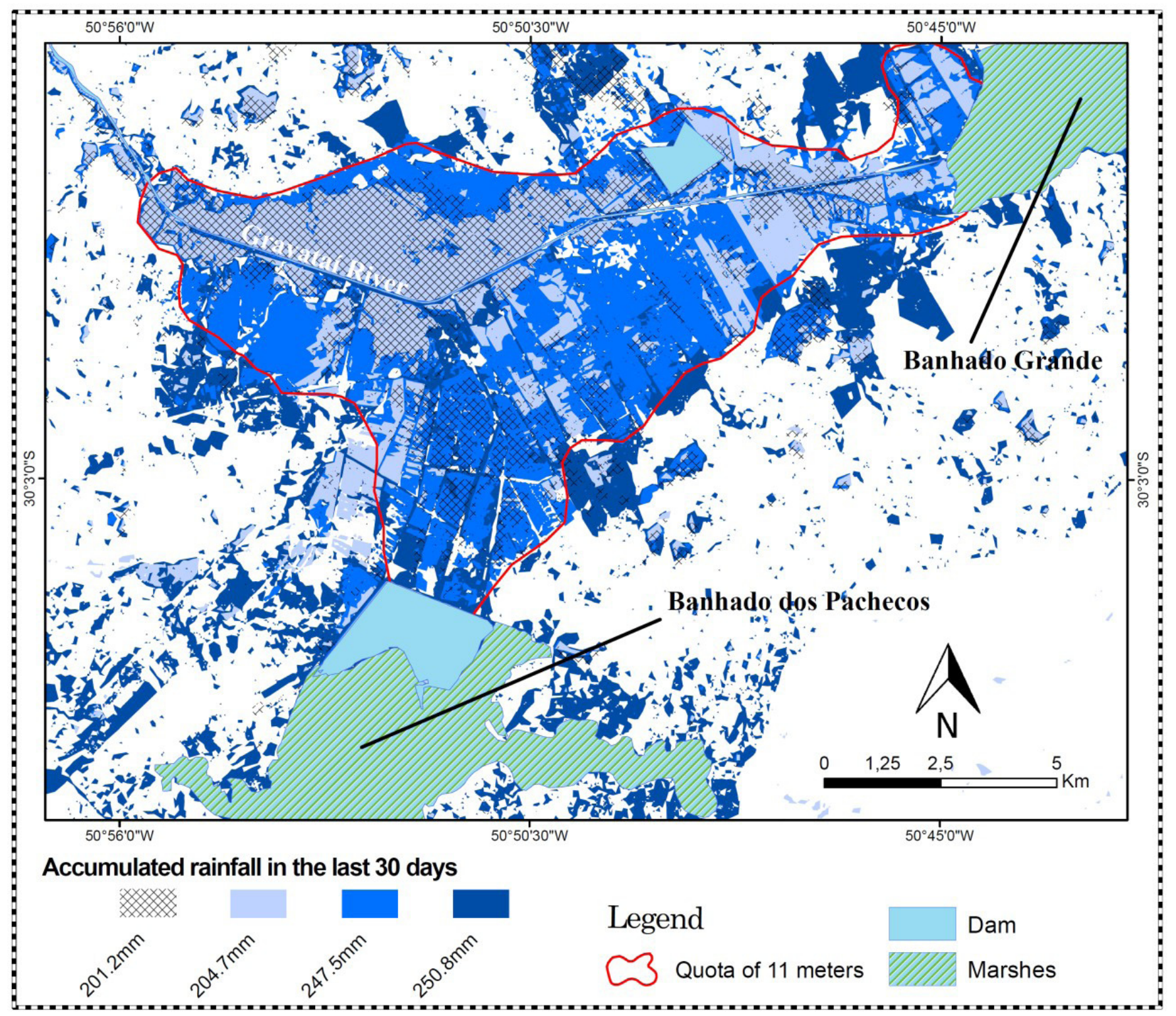

Figure 7. Connectivity among EPABG Wetlands, from NDWI images.

\section{FINAL CONSIDERATIONS}

Connectivity, considering the hydrogeomorphological attributes, means that each river basin has its own hydrological regime. Thus, understanding the dynamics of the basin through the characterization of flood pulses and connectivity levels is fundamental in the design, classification and management of wetlands.

Thus, this work is expected to contribute to studies aimed at the understanding and dynamics of connectivity and flood pulses in wetlands, which are fundamental in the maintenance of hydrological interactions within the hydrographic basins.

Changes in the dynamics of connectivity can affect the occurrence of plant and animal species that require flooding processes to complete their life cycle. Also, nutrient cycling and primary productivity may be affected by the change in connectivity because ecological processes are directly related to flood pulses.
In this way, the characterization of the flood pulses and the connectivity become fundamental for the characterization and understanding of the dynamics of the wetlands.

Studies on wetlands have become increasingly relevant, especially considering that for Rio Grande do Sul there is no detailed survey of their wetlands. In fact, this is a prerequisite for a coherent policy, considering the sustainable management and protection of these areas of great importance for the maintenance of biodiversity.

For EPABG, it was verified that the occurrence of rainfall above $247 \mathrm{~mm}$ in the 30 days prior to obtaining the satellite image creates an extensive area of connectivity between the floodplain of the Gravataí River and the corridor that connects the Great Plains To the plains of the Pachecos, forming a triangle between the different geological / geomorphological compartments. Has two types of connectivity: wetlands, wetlands connectivity, allowing 
interactions between environments with palustrine deposits and lagoon bottom; and wetlands-stream connectivity, linking alluvial deposits and Gravatai River flood plain with the lagoon and palustrine background.

It was also found that when the rainfall on the 30 days preceding the date of the image is approximately $200 \mathrm{~mm}$, has been in EPABG connectivity between the river Gravataí and Banhado Grande, called (wetlands-stream connectivity), which connects The paludal deposit with deposits of flood plain of the river.

\section{REFERENCES}

ACCORDI, I. A. O Sistema Banhado Grande como uma área úmida de importância internacional. In: SIMPÓSIO DE ÁREAS PROTEGIDAS, 2., 2003, Pelotas. Anais... Pelotas: UFPEL, 2003. p. 56-63. CD-ROM.

ACCORDI, I. A.; HARTZ, S. M. Distribuição espacial e sazonal da avifauna em uma área úmida costeira do sul do Brasil. Revista Brasileira de Ornitologia, v. 2, n. 14, p. 117-135, 2006.

AMOROS, C.; ROUX, A. L. Interaction between water bodies within the floodplains of large rivers: function and development of connectivity. Münstersche Geographische Arbeiten, v. 29, n. 1, p. 125-130, 1988.

ANA - AGÊNCIA NACIONAL DE ÁGUAS. Hidroweb. Brasília, 2016. Available from: <http://hidroweb.ana.gov.br/default.asp>. Access on: 24 may 2016.

BRASIL. Constituição (2000). Lei no 9.985, de 18 de julho de 2000. Institui O Sistema Nacional de Unidades de Conservação da Natureza e Dá Outras Providências. Diário Oficial [da] República Federativa do Brasil, Brasília, DF, 19 jul. 2000. Available from: < http:// www.mma.gov.br/port/conama/legiabre.cfm?codlegi $=322>$. Access on: 20 mai. 2016.

BRASIL. CPTEC - Centro de Previsão de Tempo e Estudos Climáticos. INPE - Instituto Nacional de Pesquisas Espaciais. (Org.). El Niño. Brasília, 2015. Available from: <http://enos. cptec.inpe.br/>. Access on: 14 may 2016.

BRENNER, V. Proposta metodológica para renaturalização de trecho retificado do rio Gravatai-RS. 2016. 94 f. Dissertação (Mestrado) Programa de Pós-graduação em Geografia, Universidade Federal do Rio Grande do Sul, Porto Alegre, 2016.

BRENNER, V.; GUASSELLI, L. A. Índice de diferença normalizada da água (NDWI) para identificação de meandros ativos no leito do canal do rio Gravataí/RS - Brasil. In: SIMPÓSIO BRASILEIRO DE SENSORIAMENTO REMOTO, 16., 2015, João Pessoa. Anais... São José dos Campos: INPE, 2015. p. 3693-3699. Available from: <http://www.dsr.inpe.br/sbsr2015/files/p0727.pdf>. Access on: 20 set. 2016.
COWARDIN, I. M., CARTER, V.; GOLET, F. C.; LA ROSE, E. T. Classification of wetlands and deepwater habitats of the United States. Washington: Department of the Interior, Fish and Wildlife Service, 1979. 131 p.

CUNHA, C. N.; PIEDADE, M. T. F.; JUNK, W. J. Classificação e delineamento das áreas úmidas brasileiras e de seus macrohabitats. Cuiabá: EdUFMT, 2015. 165 p.

DIEGUES, A. C. S. (Coord). Inventário de Áreas Úmidas do Brasil. São Paulo: Programa de Pesquisa e Conservação de Áreas Úmidas no Brasil, USP/UICN/FORD, 1990. Versão Preliminar.

FARR, T. G.; ROSEN, P. A.; CARO, E.; CRIPPEN, R.; DUREN, R.; HENSLEY, S.; KOBRICK, M.; PALLER, M.; RODRIGUEZ, E.; ROTH, L.; SEAL, D.; SHAFFER, S.; SHIMADA, J.; UMLAND, J.; WERNER, M.; OSKIN, M.; BURBANK, D.; ALSDORF, D. The Shuttle Radar Topography Mission. Reviews of Geophysics, v. 45, n. 1, 2007.

FRAGOSO JÚNIOR, C. R.; NEVES, M. G. F. P. Regularização de varões. Maceió: Ctec/UFAL, 2015. Available from: <http:// docslide.com.br/documents/hidrologia-carlos-ruberto-fragoso-jrhttpwwwctecufalbrprofessorcrfj-marllus-gustavo-ferreira-passosdas-neves-httpwwwctecufalbrprofessormgn.html>. Access on: 20 may 2016.

GAO, B. C. NDWI a normalized difference water index for remote sensing of vegetation liquid water from space. Remote Sensing of Environment, v. 58, n. 1, p. 257-266, 1996.

GUASSELLI, L. A. Dinâmica da vegetação no Banhado do Taim, RS. 2005. 173 f. Tese (Doutorado) - Universidade Federal do Rio Grande do Sul, Porto Alegre, 2005.

GUASSELLI, L. A.; ETCHELAR, C. B.; BELLOLI, T. F. Os impactos do cultivo de arroz irrigado sobre as áreas úmidas da Área de Proteção Ambiental do Banhado Grande do rio Gravataí - RS. In: SIMPÓSIO BRASILEIRO DE SENSORIAMENTO REMOTO, 15., 2013, Foz do Iguaçu. Anais... São José dos Campos: INPE, 2013. p. 447-452. Available from: < http://www.dsr.inpe. br/sbsr2013/files/p1428.pdf>. Access on: 20 mai. 2016.

GUIMARÃES, T. F. R. Conectividade e padrões de riqueza e diversidade de espécies de peixes nas lagoas do litoral norte do Rio Grande do Sul, Brasil. 2009. 37 f. Monografia (Trabalho de Conclusão de Curso) - Universidade Federal do Rio Grande do Sul, Porto Alegre, 2009. Available from: <https://www.lume.ufrgs.br/bitstream/ handle $/ 10183 / 26172 / 000757342 . p d f$ ? sequence $=1>$. Access on: 8 may 2016.

JUNK, W. J.; BAYLEY, P. B.; SPARKS, R. E. The flood pulse concept in river-floodplain systems. Canadian Journal of Fisheries and Aquatic Sciences, n. 106, p. 110-127, 1989. 
JUNK, W. J.; PIEDADE, M. T. F. Áreas Úmidas (AUs) brasileiras: avanços e conquistas recentes. Boletim ABLimno, v. 41, n. 2, p. 20-24, 2015.

KROB, A. J. D.; MENESES, B. A.; CASTILHO, C. S.; XIMENES, S. S. F.; KINDEL, A.; MAHLER JUNIOR, J. K. F. Definição de corredores ecológicos como estratégia de proteção de importantes remanescentes de áreas úmidas e conservação do cervo-do-pantanal (blastocerus dichotomus) no Rio Grande do Sul. In: CONGRESSO BRASILEIRO DE UNIDADES DE CONSERVAÇÃO, 8., 2015. Anais... Corumbá: Fundação O Boticário, 2015.

MCFEETERS, S. K. The use of the Normalized Difference Water Index (NDWI) in the delineation of open wáter features. International Journal of Remote Sensing, v. 17, n. 7, p. 1425-1432, 1996. http://dx.doi.org/10.1080/01431169608948714.

MCFEETERS, S. K. Using the Normalized Difference Water Index (NDWI) within a Geographic Information System to Detect Swimming Pools for Mosquito Abatement: a Practical Approach Stuart. Remote Sensing, v. 5, n. 7, p. 3544-3561, 2013. http://dx.doi. org/10.3390/rs5073544.

MENEGHETTI, J. O. Lagunas uruguayas y sur de Brasil. In: CAVENARI, P.; DAVIDSON, I.; BLANCO, D.; CASTRO, G.; BUCHER, E. (Ed). Los humedales de America del Sur: uma agienda para la conservación de La biodiversidade y politicas de desarollo. Buenos Aires: Wetlands International, 1998.

NEIFF, J. J. El régimen de pulsos en ríos y grandes humedales de Sudamérica. In: MALVÁREZ, A. I. (Ed.). Tópicos sobre bumedales subtropicales y templados de Sudamérica. Montevideo: UNESCO, 1999. p. 90-139. Available from: http://unesco.org. uy/ci/fileadmin/ciencias $\% 20$ naturales/mab/8.pdf $>$. Access on: 5 de jul. de 2016 .

NIELSEN, S. D. Geomorfologia da bacia do rio Gravataí - RS. Porto Alegre: CPRM/METROPLAN, 1994. Available from: < http:// www.ecologia.ufrgs.br/labgeo/arquivos/downloads/dados/Bacia_ Gravatai/Referencias/Proteger_Bacia_Gravatai_1_Geomorfologia. pdf>. Access on: 20 may 2016.

PRINGLE, C. M. What is hydrologic connectivity and why is it ecologically important. Hydrological Processes, v. 17, n. 13, p. 26852689, 2003. http://dx.doi.org/10.1002/hyp.5145.

RAMSAR. The Ramsar Library: Information sheet on Ramsar Wetlands. Gland: The Ramsar Convention, 1971.

RIO GRANDE DO SUL. Metroplan. Barragem no Rio Gravataí sai em 2015. Porto Alegre, 2014. Available from: <http://www. metroplan.rs.gov.br/conteudo/1715/?Barragem_no_Rio_Gravataí_ sai_em_2015>. Access on: 20 maio 2016.
ROCHA, P. C. Geomorfologia e conectividade em ambientes fluviais do alto rio Paraná, Centro-sul do Brasil. Boletim Geográfico, v. 28 , n. 2 , p. $157-176,2010$.

ROCHA, P. C. Geomorfologia e áreas inundáveis na planície fluvial do alto rio Paraná. Revista Geográfica Acadêmica, v. 5, n. 1, p. 98-117, 2011a.

ROCHA, P. C. Sistemas rio-planície de inundação: geomorfologia e conectividade hidrodinâmica. Caderno Prudentino de Geografia, v. 1, n. 33 , p. $50-67,2011$ b.

ROCHA, P. C. Dinâmica sedimentológica, escoamento superficial e conectividade na bacia hidrográfica do rio do Peixe, Oeste Paulista - Brasil. In: SIMPÓSIO DE GEOGRAFIA FÍSICA E APLICADA (SGFA), 16., 2015, Teresina. Anais... Teresina: UFPI, UESPI , 2015. p. 3210-3216.

ROCHA, R. R. A.; ROCHA, P. C. Sistemas Rio-Planície de Inundação: geomorfologia e conectividade hidrodinâmica. Tópos, v. 1, n. 6, p. 81-112, 2007.

ROLOM, A. S. Áreas úmidas artificiais: as lavouras de arroz no Rio Grande do Sul. Revista do Instituto Humanitas, v. 433, n. 13, 2013.

ROLON, A. S.; HOMEM, H. F.; MALTCHIK, L. Aquatic macrophytes in natural and managed wetlands of Rio Grande do Sul State, Southern Brazil. Acta Limnologica Brasiliensia, v. 1, n. 22, p. 133-146, 2010. http://dx.doi.org/10.1590/S2179-975X2010000200003.

ROSA, M. R. Processo depriorização das Áreas Úmidas brasileiras. Brasília: Ministério do Meio Ambiente, 2009. Available from: <http:// www.mma.gov.br/estruturas/205/_arquivos/mma_apres_areas_ umidas_26maio2009b.pdf>. Access on: 20 may 2016.

ROSSATO, M. S. Os climas do Rio Grande do Sul: variabilidade, tendências e tipologia. 2011. 253 f. Tese (Doutorado em Geografia) - Universidade Federal do Rio Grande do Sul, Porto Alegre, 2011.

SANTOS, P. R. A.; GABOARDI, C.; OLIVEIRA, L. C. Avaliação da precisão vertical dos modelos SRTM para a Amazônia. In: SIMPÓSIO BRASILEIRO DE SENSORIAMENTO REMOTO, 7., 2005, Goiânia. Anais... São José dos Campos: INPE, 2005. p. 4473-4480. Available from: < http://marte.sid.inpe.br/col/ltid.inpe. br/sbsr/2004/11.19.16.24/doc/4473.pdf> . Access on: 20 set. 2016.

SCOTT, D. A.; JONES, T. A. Classification and inventory of wetlands: a global overview. Vegetatio, v. 118, n. 1, p. 3-16, 1995. http://dx.doi.org/10.1007/BF00045186.

TOMAZELLI, L. J.; VILLWOCK, J. A. O Cenozóico no Rio Grande do Sul: geologia da planície costeira. In: HOLZ, M.; DE ROS, L. F. (Ed.). Geologia do Rio Grande do Sul. Porto Alegre: CIGO/ UFRGS, 2000. p. 375-406.

USGS - UNITED STATES GEOLOGICAL SURVEY. Reston, 2016. Available from: <http://earthexplorer.usgs.gov/>. Access on: 20 may 2016. 
VANDERHOOF, M.; ALEXANDER, L. C.; TODD, M. J. Temporal and spatial patterns of wetland extent influence variability of surface water connectivity in the Prairie Pothole Region, United States. Landscape Ecology, v. 31, n. 4, p. 805-824, 2016. http:// dx.doi.org/10.1007/s10980-015-0290-5.

WARD, J. V.; STANFORD, J. A. Ecological connectivity in alluvial river ecosystems and its disruption by flow regulation. Regulated Rivers: Research and Management, v. 11, n. 1, p. 105-119, 1995. http://dx.doi.org/10.1002/rrr.3450110109.

\section{Authors contributions}

João Paulo Delapasse Simioni: Bibliographic review, acquisition of satellite images, acquisition and treatment of precipitation and Gravataí river level data. Mapping and analysis of results.

Laurindo Antonio Guasselli: Text revision, study orientation, results analysis and final considerations.

Cecilia Balsamo Etchelar: Analysis and discussion of results, methodological review and revision of the text. 